\title{
Batik and Pewter: Symbols of Malaysian Pianissimo
}

\author{
Barbara LEIGH
}

\begin{abstract}
National symbols are part of a country's historical material culture. They are an indication of how those in power within the country wish the nation to be represented on the global stage. Intersecting with such cultural and political factors are the ways in which economic enterprises construct objects or artifacts that over time assume the status of national icons. The focus in this article is on two examples of Malaysian material culture that are accepted by visitors and promoted by the government as national symbols - batik and pewter. The making of these national material cultural identities provides a window to broader sociological dynamics. These can be viewed as a manifestation of a process where the government negotiates a softly articulated balance between the interests and concerns of its political constituency and the rigorous demands of the market - a Malaysian pianissimo.
\end{abstract}

In an era of globalization, the production and consumption of material symbols to represent or encapsulate aspects of national identity usually embodies the economic decisions of major business players who link with political stakeholders for mutual advantage. For example, the staging of the 2000 Olympic Games in Sydney saw certain businesses having the "rights" to produce particular icons that were promoted as depicting "Australia". Similarly, when the Commonwealth Games were staged in Kuala Lumpur in 1998, the selling of Malaysia to the outside world included a wide range of artifacts.

This article is an attempt to tease out the processes by which these choices are made by examining the role of the Malaysian state ${ }^{1}$ and the extent to which it protects the interests of a particular community; the economic imperative of business in a country that has opened its doors 
to global vicissitudes; and the interplay between these two. The process can be seen as a dynamic shifting between the market and the state. The making of national material cultural identities provides a window to broader sociological dynamics. These can be viewed as a clash between differences, which are a manifestation of competing ideologies and at times races, or a process where the government negotiates a softly articulated balance between the interests of its political constituency and the demands of the market.

\section{National lcons}

Governments of all nations use material symbols to represent or encapsulate aspects of national identity. These are promoted domestically and internationally along with the flag as a symbolic part of the nationmaking and nation-consolidating exercise. But nationalism does not just draw upon the past. It fuses its embodiment of the past with the present. In that sense, the Malay ${ }^{2}$ élite promotes modernity and "newness" as a highly significant component of nationalism. For people who are part of the Malaysian élite, mobile phones, designer clothing, mini laptops, and expensive cars have become part of their way of life. ${ }^{3}$ Although the Petronas towers are not "consumed" in the usual sense of the word, they are consumed psychologically and represent a symbol or icon of this modern aspect of Malaysian identity.

Sometimes particular crafts are promoted as representative of the nation because they are linked with some "golden age". Malaysia's identity at the beginning of the twenty-first century lies primarily in symbols that signify the "modern" and those that link in some way with the court culture of the Malay sultanate (Leigh 2000). Such material symbols may be the Petronas towers, the development of Putrajaya, the Proton car, the kite as it appears on the tail of Malaysian Airlines, Islamic calligraphy, the hibiscus flower, a wide range of pewter products, textiles - batik and songket, and the dagger which is known as kris. Within the states of Sabah and Sarawak, a wide range of fibreware, beadwork, indigenous crafts and textiles are also sold as distinctively representative of the region. ${ }^{4}$ 


\section{The Intervention of the State}

The state is often a key player in the production (and protection) of cultural identities in what in many ways is a borderless economic world. This has socio-cultural ramifications as well as allowing us to see the political and economic dimensions of the state's decisions. Panitch (1996, pp. 84-85) states that "to a considerable extent the leaders of states have not only chosen to be integrated into, but have shaped the direction of globalization". But not all writers would agree with this view. Kenichi Ohmae (2000, pp. 207-11) sees governments rapidly privatizing and losing control over processes that were once considered the preserve of the nation-state. He sees the shedding of assets, the ending of protectionism and the lowering (or abandoning) of tariffs as a key aspect of the process. There is no doubt that this has been true for Malaysia just as it has been for the Western world in the post-Thatcher era.

However, in the specific instance of batik production, the state is a key player in facilitating the industries involved. The leaders of the Malaysian state (and through them, the producers of Malaysian batik) are not victims of globalization, but are very much pro-active players in the production of material cultural identities. Geoffrey Garrett (2000, pp. 227-35) sees the state as a player that intervenes on behalf of its constituency, and links the state intervention to the process of democracy and domestic political dynamics that give rise to the need for welfare and a degree of protection. In order words, he posits that because governments desire to be elected and re-elected, state intervention is also influenced by a non-market force.

Garrett does not, however, acknowledge the partisan role that the state can play in the intervention process. Precisely in the Malaysian case such a partisan role is played by the state which formulated and promulgated a policy of affirmative action on behalf of Malays. As such the state intervenes for the welfare of not the whole society but, rather, for a particular segment (and in many cases only a minority within that segment).

\section{International Tourism and National Identity}

In the production of a cultural identity, a nation does not just exist on its own, but it acts in response to others. ${ }^{5} \mathrm{~A}$ significant arena where the production of a cultural identity takes place is in international trade tourist trade in particular. There are sites situated within the nation where tourists visit, consume, and signify their acquisition of cultural capital. After visiting nature resorts or places of antiquity or capital cities, they bring their accumulation of cultural icons and their notions of the visited nation or site back "home". Nations prepare for tourists now in highly sophisticated ways. They sell "image" as well as artifacts, and Malaysia is no exception. Tourism is not only big business for it also engenders far-reaching psychological changes. The production and consumption processes reinforce images that the government wishes to promote, and the tourist participates and unthinkingly colludes in this process as a consumer.

Whilst it is true that one facet of globalization gives impetus to cultural homogenization, namely, "the diffusion of standard consumer goods throughout the world" (Mittelman 1996, p. 2), global tourism also gives impetus and reinforcement to the ongoing creation of national identities. The average tourist wishes to visit "unique" places that can be captured on film; they wish to purchase items (souvenirs or antiques) that signify the identity of the places they are visiting. They are interested in items that are not culturally homogenous. (Although the converse argument can also be made that souvenirs throughout the world are developing a "sameness" in form, with a difference only in design.) Many tourists are not concerned with how that identity was created. Nor are they particularly concerned that from a plethora of possible souvenirs, certain items are both more readily available and are more frequently promoted in the tourist literature as "representative" of the nation they are visiting. Such phenomena are seen as part of thoe "taken-for-granted" aspect of the visited nation. In fact, we are witnessing the "making of difference" between tourist destinations, wherein the international tourist demand for consumption, the nation-making activities of the political élite, and the wealth-making activities of private economic internationally oriented enterprises all coalesce. What we are seeing at the beginning of the twenty-first century is a "thickening" or an "increase in tensity" of these global networks (Keohane and Nye Jr. 2000, p. 112). 
This analysis draws attention to the practices of producer and con sumer, whilst at the same time recognizing that the engine for nationa definition lies both within the structures of the state and also withir market-led decisions of major private enterprises that are "smiled upon" by the state. Certain material items, whether they be brassware antiques or mass-produced key rings are fostered, promoted, marketed, and consumed, as being quintessentially "Malaysian". Cox (1996, p. 25), drawing on the work of Braudel, cites his notion of longue duree. This is a concept of time in which the length and duration allows us to better understand historical structural change. People feel an identity with older items of material culture that were used by their grandparents and their great-grandparents. Such cultural identity-making involves many generations of time in which seepage occurs to the point of feeling "natural". It is these cultural roots that governments call upon when establishing national material symbols of identity. Sometimes, material cultural identities can be formed quite rapidly when they link with roots that have long meaning. Kuching is the capital of the East Malaysian state of Sarawak. Kuching means "cat" in Malay. That is a linguistic root that goes a long way back in time. However, the promotion of the cat as representative of Kuching has been a political and economic venture that has occurred solely within the term of the current Chief Minister, Datuk Patinggi Taib Mahmud (1981 to the present). Prior to that, Kuching was recognized as being a name that originated from either the Chinese term "Kochin" meaning "harbour", or from "mata kuching" ("cat's eye" fruit - a fruit that was prolific in the area). Statues of cats, a cat museum, cat T-shirts, and a plethora of other cat souvenir paraphernalia have all proliferated in only the last two decades. The combination of longué dureé and political expediency can be seen in the making of "cat" material cultural icons in Kuching.

International tourists are now important agents in the affirming of material cultural identities simply because they are significant consumers of Malaysian artifacts. They have specific demands and these in turn fashion the range, design, and nature of what is sold as "Malaysian". In 1992 the Malaysian government spent RM534 million to boost the tourist industry. In that same year, Malaysia received more visitors than lany of its neighbours in the Association of Southeast Asian Nations (ASEAN). It was the year in which tourism was the fourth biggest for'eign exchange earner after manufacturing, petroleum and palm oil. ("Visitors Flock to Utopia of the Asia-Pacific Region", South China Morning Post, 28 August 1993). Based on these figures, the Malaysian government determined that 1994 would be "Visit Malaysia Year". That year saw a 10 per cent increase in the number of visitors to Malaysia and was deemed to be a success. ${ }^{6}$ Many of these visitors are from Singapore and they do not fall into the category of tourist that I am describing. Even if we were to discount half the tourists as being from Singapore, then there are still significant numbers of tourists seeking a souvenir that connotes "Malaysia".

In 1997 the economic crisis that hit the East Asian region also affected Malaysia. In addition, the forest fires in Sumatra and Kalimantan, caused primarily by companies clearing massive acreage in preparation for the planting of palm oil, created a murky haze over most of the Malay archipelago. Tourism was badly affected and the number of visitors declined dramatically; for example, tourist numbers were down to 5.5 million in 1998. Nevertheless, although the tourist receipts fell in 1998 to RM9.3 billion, it remains the third biggest foreign exchange earner after manufacturing and palm oil. ${ }^{7}$ At the beginning of the twenty-first century, numbers of visitors are on the increase.

The craft or souvenir industry is just one cog in the giant tourist industry wheel. Airlines, ground-transport, tours and guides, hotels, food stores, and entertainment are all connected to the tourist trade. Malaysian cultural identities are not static and they are socially constructed in a global milieu where there are a number of significant players. International and domestic tourists make choices as they consume. Cultural identity formation is always linked to the tangible, to the abstract manifested in the material. In a climate of thickening globalization, the state and the market are significant players, competing not just for dollars, but in the case of batik and pewter, both legitimately represent the state to the outside world. 


\section{Batik: A Protected Industry}

Malaysian batik is a state-protected industry. Many élites lay claim to past grandeur in order to buttress the present; Malaysian élites are nc exception. Malaysia's Malay political élite lays claim to a vision of Malay sultanate splendour that spread throughout the archipelago in the six. teenth and seventeenth centuries. The material items used within these court cultures were seen as signifying royalty and grandeur, and drew on the skills of court artisans who lived in the precincts of the royal sultanate compound. The motifs and designs used on those items continue to be reproduced on modern artifacts or modern reproductions of the old items. This may be seen as the "reinvention of tradition" in the Hobsbawm sense. It can also be seen as a material manifestation of Braudel's longué dureé. The Malay world was a loose collection of sultanates that rose and fell in importance throughout the archipelago, and thus the centre of perceived high culture shifted depending on those vicissitudes. The Javanese court kingdoms were admired and at times were an integral part of the string of littoral centres of power that existed throughout Southeast Asia. Javanese culture was also admired, as were its textiles.

Although Malaysian batik is promoted strongly by the government as a symbol of the nation, batik enterprises are relatively new in Malaysia. The history of the industry is that a number of Javanese migrants settled on the Malay peninsula and set up small home production centres in the early years of the twentieth century (Arney 1987, p. 23). These were mainly on the East Coast in the vicinity of Kota Bharu and Kuala Trengganu and, until the 1990s, the defining characteristic of these batik enterprises was their small scale. The batik enterprise was often only a household; sometimes it was an extended family, and occasionally it was a small business. The other defining characteristic of these enterprises was that they were primarily rural or outer urban in nature, reflecting the composition of the work-force engaged in the industry. The cloth that they produced was different from their Indonesian cousins, and designs came to have a distinctively Malaysian form.

By the end of the twentieth century, batik production in Malaysia has a number of medium-scale state and private enterprises that are closely linked with government. Batik production has been promoted through a number of government bodies that were established to specifically promote Malay-Malaysian handicrafts. The Handicraft Development Centre was established in 1967. Batik Malaysia Sdn. Bhd. was established in 1968 and is the major promoter. It co-operates with MARA (Majlis Amanah Rakyat Act - Council of Trust for Indigenous People Act) in the conducting of training schemes at the various ITM (Institute Teknologi MARA) that have been set up around the country. The Malaysian Handicraft Board (Lembaga Kraftangan Malaysia) was established in 1973 (Wan Hashim Wan Teh 1996, pp. 5, 6). The establishment and funding of these bodies was assisted by the Malaysian government's affirmative action policies to specifically assist Malays, commencing in 1971. The political historian Gordon Means outlined this policy:

The government formulated a set of economic strategies and policy goals which proposed to ensure that Malays gained an improved share of the country's wealth as well as more equitable access to jobs and positions of influence in the more modern and dynamic sectors of the economy. (1991, p. 23)

The Malaysian Handicraft Board became the Malaysian Handicraft Development Corporation (MHDC), Perbadanan Kemajuan Kraftangan Malaysia, in 1979. Since then, this body, commonly referred to as Kraftangan, has targeted bumiputera (indigenous) firms in various regions in Malaysia for the production, promotion, and marketing of specific crafts. These aim to distribute craft production geographically throughout the country. A number of places on the East Coast have been designated for batik production and those on the West Coast for pewter production. Other crafts are designated to other parts of the country.

The objective of Kraftangan is:

to create a dynamic craft industry through the creation of a vibrant, resilient and entrepreneurial community of crafts people with passion for their work and intellectual curiosity pertaining to all aspects of it. These crafts people are expected to maintain the identity, yet creating 
crafts for a market both local and international; keeping pace with changing times and changing tastes, and making their crafts economically viable without sacrificing their aesthetic values through craft commercialization. In short, as keepers of the nation's heritage, they will create new traditions out of existing ones and make their works truly living crafts. (Malaysia Yearbook 1996, p. 483; author's emphasis)

The words in italic highlight the political as well as the aesthetic and eco. nomic role that Malaysia's crafts people who are sponsored by Kraftangan, are expected to perform. Kraftangan now promotes crafts throughout the country and the Malaysian Tourism Promotion Board promotes them in its offices throughout the world. While designs tend to be primarily floral, geometric forms, splashes of colour, and occasionally, butterflies and fish are also to be seen. The technique is one of painting a waxed design and then filling in the enclosed spaces with a variety of colours. Both the designs and techniques are different from Indonesian batik.

This engagement in the economic life of the nation does not necessarily return a profit, and, indeed, a number of Kraftangan stores only exist because they are subsidized. They operate on civil service time, do not keep long commercial hours and are often over-staffed. What is significant is that their produce is a cultural affirmation of a particular notion of the Malaysian nation. The history of Malay sultanate splendour and its associated material culture is privileged over and above the history of diverse immigrant cultures to the peninsula and their associated items of meaning and cultural significance.

At the end of the twentieth century, batik is a major craft promoted by Kraftangan. The most powerful measure the Malaysian government has taken to protect the industry is to prohibit imports of batik from anywhere outside Malaysia, particularly on the peninsula. ${ }^{8}$ This is the highest form of protection for the local industry, as without such a policy, the local industry could be swamped by imports from its neighbour, Indonesia. The Indonesian challenge is particularly potent because its labour is cheaper and its industries are very responsive to particular market demand. Such a situation may well arise if there were no protection from the Malaysian state.
Within Malaysia, MARA conducts training schemes for batik production for a Malay clientele. There is subsidization of commercial dyes and a range of white synthetic fabric from China for use by Malay batik firms. There is no indication that batik itself is a highly profitable industry, unless the firm is able to secure a reasonable number of guaranteed orders. In other words, domestic demand fluctuates and the successful medium-scale private enterprises tend to have links that give some guarantee of demand.

The Malaysian state forges its identity in relation to items of material culture as part of the dynamic process of state-making. In order to identify with state-sanctioned items of material culture, people must give their allegiance or consent to those in authority. At times other than elections, the authorities use pageantry. ${ }^{9}$ Highlighting national icons provides tangible representations with which people can identify as "theirs" in a sea of cultural homogeneity. Conversely, the failure to identify with such icons is indicative of lack of consent and may result in contestation. During the Commonwealth Heads of Government Meeting (CHOGM) and the Asia-Pacific Economic Co-operation (APEC) meeting in Kuala Lumpur, the leaders were all given batik shirts. Malaysians will often present visitors with a piece of batik, whether it be a shirt, a tie, a bag, a scarf, or a length of material, as a sign of their respect, and as an indication that this is a particularly Malaysian gift. Hotels display and sell batik art. Malaysian Airline hostesses wear batik dress. Glossy illustrated brochures that depict batik boutique outlets are given to new arrivals. Domestic and international airport terminals have exclusive textile stores that promote richly decorated batik items. Formal gatherings often require batik shirt for men. It is the Malaysian formal dress code for both men and women. The government is a major player in the construction of material cultural identities, in so far as it continues to give its imprimatur to Malaysian batik.

\section{Royal Selangor International - A Global Success Story}

Unlike the firms that produce batik, one of the major producers of pewter, Royal Selangor International, is a global firm. Although it is 
owned by a Malaysian Chinese family, the firm is closely linked to $t$ Malaysian government and its produce is regarded as part of the politis and social process of cultural identity-making.

Royal Selangor International is the largest firm in Malaysia that pr duces items that are bought and given as representative of Malaysia. A though beginning as a solely Malaysian firm, this business is now inte national as its name suggests. In 1997, Royal Selangor International, t $t$ largest pewter producer in the world, turned the economic tables on $\mathrm{i}$ former colonial masters and took over the prestigious British firm I Comyns Silver, a firm that had been in existence for three centurie Now Comyns' techniques and designs are being produced and adapte on the other side of the world. ${ }^{10}$

An indication of Royal Selangor International's commercial succes lies in the fact that from 1,794 manufacturing companies listed in th Malaysian Manufacturers Directory in 1997, the Managing Director o Royal Selangor International Sdn. Bhd. (Datuk Yong Poh Kon) is lister as one of only four vice-presidents. Such a position in Malaysian manu facturing circles would seem to be a solid indicator of the firm's com. mercial success.

The firm was previously known as "Selangor Pewter" and it attained the appellation "Royal" in 1992. Because the firm was known as "Selangor Pewter", the Royal family of Selangor became its patron. Thus the title "Royal" here indicates the Selangor royal family patronage. Present also at the launch was Dato' Seri Rafidah Aziz, the Minister for Trade and Industry. Together with the Director of Royal Selangor, this was a heady combination of royalty, the state, and global enterprise. ${ }^{11}$ Annual sales figures are not listed for Royal Selangor International, even though they are listed for many other companies. This is because of the family business structure of the company. ${ }^{12}$ It dominates the field of giftware and jewellery within Malaysia. During the Commonwealth Games in 1998, Royal Selangor International produced trophies and gifts for international dignitaries. Pewter gifts are given in the same way that batik is used - as an indication of respect and honour that is associated with the state of Malaysia.
By working closely with the government, the firm has captured the psychological domain as well as the economic field. The company is very sensitive to market wishes and has literally thousands of items and designs for all tastes. Designers are specifically employed for particular markets. The designs are constantly under review and are changed according to market flows. For those who wish to purchase something traditional, the sultanate design heritage is brought to life in a modern context. For those who want to present a completely modern Malaysian persona, there are items that fit this category. ${ }^{13}$ For those who want a religious item, there are many products from which to choose, including a pewter clock that indicates Muslim prayer times and the direction of Mecca (by way of an embedded magnetic compass).

From its small beginnings as a pewter production business in the early years of the twentieth century, Royal Selangor International Sdn. Bhd. now has hundreds of authorized dealers (in addition to its myriad outlets) around the country. Every major airport in Malaysia has a Royal Selangor International store. It has national offices and extensive retail outlets in Australia, Canada, Hong Kong, Japan, Singapore, Thailand, the United Kingdom, and the United States. Australia alone has over a thousand outlets in specialist and general stores. In addition, there are many other commercial outlets around the globe, for example, in Beijing, Shanghai, Brunei, and Copenhagen. Customers are able to shop via the Internet. It tailors its products and designs to the markets. For example, in Malaysia, there is pewter kris for sale; for China there is a four-season vase and animals representing the Chinese calendar year; ${ }^{14}$ for Japan, there are sake vessels; for Scandinavia, there are dishes, goblets, and vases with smooth lines and the incorporation of wooden elements; for the United Kingdom, there are tea sets; for the United States, there are coffee sets; and for Australia, there is a variety of beer mugs. It is this firm, with its commercial tentacles extending from its Malaysian heartland throughout the globe that is indicative of the type of rapid change taking place in market production in Malaysia. The Malaysian government and Malaysian royalty see the firm as one with which it is mutually beneficial to work. 


\section{Malaysian Pianissimo}

The Malaysian government is softly allowing both market and stat room to breathe. It appeals to the constituency that wishes to trade glo bally and places no hurdles in its path - in fact, it is encouraging it profit-making ventures. In return, such a successful enterprise is support ive of government initiatives and among its diverse offerings, strongl promotes souvenirs that imitate Malay antiques and employ sultanat design forms. At the same time, the government is providing very stron protection to a relatively young Malay-based industry. Not only is $\mathrm{i}$ supporting the industry, it is incorporating and heavily promoting the material culture that it produces as one of the symbols of the nation.

National boundaries are becoming increasingly irrelevant for the movement of goods and capital. But countries' boundaries can be ver. significant for the reinforcing and reshaping of national icons. Batik pro duction in its present form in Malaysia exists because of, and for, the state. It is protected from its neighbour, Indonesia - a nation with : cheaper and larger batik industry. Batik is part of the Malaysian gov ernment's effort to promote Malay businesses. Malaysian batik exist. also to promote a Malay cultural identity. Batik is promoted and con sumed as a craft with a modern Malay image, indeed for the global stagi - a "Malaysian" image.

Royal Selangor International represents the successful private sector It depicts the Malaysian embodiment of aggressive marketing in its pro duction of the traditional within the modern and the modern writ large as manifested in thousands of items that are sold around the globe. The political demand for gifts, trophies, and other awards produced by thi: firm is vast. The desire for the traditional and the modern coalesce. The "traditional" is a broad collection of the many different design tradition: existing within Malaysia, as they are translated into thousands of pew. ter products. All customers will find an item that appeals to their particular "tradition". This is the material manifestation of longué dureé The "modern" is the technology, the product, the presentation, and the international company - something with which the state likes to iden tify.
Will these two broad designations of material cultural symbols clash at some unknown stage in the future? Or will their coexistence continue to be quietly played out, accommodations made, and Malaysia's material cultural icons continue to be waxed, dyed, cast, and forged? The Malaysian people's response to globalization will be critical in determining answers to these questions.

\section{NOTES}

1. The "state" refers to the Malaysian state and not to the internal divisions akin to provinces. These are also known as states, but are not the focus of the argument.

2. The Constitution defines a "Malay" as a person who habitually speaks the Malay language, professes the Muslim religion, and conforms to Malay custom. A "Malaysian" refers to a citizen of Malaysia (of any race), although often people will refer to someone as a "Malaysian Chinese", rather than just as "Malaysian". Racial boundaries are quite marked and are exacerbated by political configurations, in which almost all parties are ethnic-based.

3. The magazine, The Malaysia Tatler, is full of advertisements for such items.

4. This article, whilst recognizing that cartoons are a primary material cultural manifestation of this phenomenon, does not deal with counter-government icons. Given the draconian nature of the Internal Security Act (ISA) whereby imprisonment can take place without trial, counter-government activities tend to be more hidden than proudly displayed.

5. Simmel's (1950) work on the making or production of the self as a social process is an apt analogy for the process that is constantly taking place within a nation.

6. Malaysia Yearbook 1995. "The Visit Malaysia Year promotion of 1994 attracted 7,197,229 visitors, whereas in 1993, 6.45 million people visited Malaysia".

7. http://www.tourism.gov.my and http://202.184.140.111/database/factlight98.xls. In 1998, income from manufacturing was RM237.6 billion; from palm oil, RM17.8 billion; and from tourism, RM9.3 billion.

8. Kain sarong batik $(6211.42900 .6211 .43900 .6211 .49900)$ is a prohibited item under item 7, Third schedule of the Customs (Prohibition of Imports) Order 1998 (Government Gazette Ref: P.U. (A) 216/98). The only exception is if a licence is approved by the Ministry of International Trade and Industry. The prohibition applies to all countries, but is particularly targeted at Indonesia. Indonesian batik is, however, available in small quantities on the duty-free island of 
Langkawi. Malaysian travellers to Indonesia are allowed to bring back Indone sian batik for their personal use only. From informal conversations, this is maximum of two pieces. This situation is unlikely to change with the introduc tion of common tariffs within the ASEAN Free Trade Area (AFTA) through th 5 per cent common effective preferential tariff (CEPT) scheme which came int effect in 2001. Prohibited items are not affected by this scheme.

9. Geertz (1980). This book is an excellent exposé of the relationship between th state and the pageantry of the populace. The essential theme retains its relevance Only the nature of the pageantry has changed. The theme is applicable across tim and space, and is pertinent to the ways in which nation-states create cultural iden tities.

10. Comyns had 35,000 patterns and designs dating back to the sixteenth and sev enteenth centuries (interview with James Ward, April 1996). In 1973, Roya Selangor Sdn. Bhd. also incorporated Selberan Jewellery into its group of com panies, and in 1992 Selberan became the sole distributor in Malaysia for Lazarr Diamonds.

11. The event was written up in the social pages of Malaysian newspapers and maga zines. See "Royal Launch", in Female, October 1992, p. 76.

12. No figures are published giving the profits, as the firm maintains its family sta tus and is not listed on the stock exchange. Correspondence with the firm con firmed this state of affairs.

13. For example, photo frames can be bought with curving tendrils of vines as in olde Malay sculptures, or with smooth lines and a hibiscus flower in the corner.

14. The Director has employed top Malaysian artists to design products for the com pany. Skilled artisans from places as far away as Scotland have also been employed

\section{REFERENCES}

Arney, Sarah. Malaysian Batik: Creating New Traditions. Kuala Lumpur: Malaysiar Handicraft Development Corporation, 1987.

Bank Negara Annual Report 1998. Kuala Lumpur: Bank Negara Malaysia, 1998.

Cox, Robert W. "A Perspective on Globalization". In Globalization: Critical Reflec tions, edited by James H. Mittelman. Boulder, CO: Lynne Reinner Publish ers, 1996.

Garrett, Geoffrey. "Partisan Politics in the Global Economy". In The Globalization Reader, edited by Frank J. Lechner and John Boli, pp. 227-35. Malden, MA Blackwell, 2000

Geertz, Clifford. Negara: The Theatre State in Nineteenth Century Bali. New Jersey Princeton University Press, 1980.

Hobsbawm, E.J. "The World Unified". In The Age of Capital 1848-1875. London:
Weidenfeld and Nicolson, 1975.

Keohane, Robert O. and Joseph S. Nye, Jr. "Globalization: What's New? What's Not? (And So What?)". Foreign Policy, no. 118 (Spring 2000), pp. 104-20.

Leigh, Barbara. The Changing Face of Malaysian Crafts: Identity, Industry and Ingenuity. Kuala Lumpur: Oxford University Press, 2000.

Malaysia Yearbook 1995. Kuala Lumpur: Berita Publishing Sdn Bhd, 1995.

Malaysia Yearbook 1996. Kuala Lumpur: Berita Publishing Sdn Bhd, 1996.

Means, Gordon P. Malaysian Politics: The Second Generation. Singapore: Oxford University Press, 1991.

Mittelman, James H. "How Does Globalization Really Work?" In Globalization: Critical Reflections, edited by James H. Mittelman. Boulder, CO: Lynne Reinner Publishers, 1996.

Ohmae, Kenichi. "The End of the Nation State". In The Globalization Reader, ed ited by Frank J. Lechner and John Boli, pp. 207-11. Malden, MA: Blackwell 2000.

Panitch, Leo. "Rethinking the Role of the State". In Globalization: Critical Reflections, edited by James H. Mittelman. Boulder, CO: Lynne Reinner Publishers, 1996.

Simmel, Georg. The Sociology of Georg Simmel, translated and edited by Kurt H. Wolff. New York: The Free Press, 1950.

Sklair, Leslie. Sociology of the Global System. Baltimore: John Hopkins University Press, 1995.

Wallerstein, Immanuel. "The Rise and Future Demise of the World Capitalist System: Concepts for Comparative Analysis". Comparative Studies in Society and History 16, no. 1 (1974).

Wan Hashim Wan Teh. Malay Handicraft Industries: Origins and Development. Kuala Lumpur: Dewan Bahasa dan Pustaka, 1996.
Barbara Leigh is Head of Asia-Pacific Studies and Senior Lecturer in Southeast Asian Stud ies, Institute for International Studies, University of Technology, Sydney. 